\title{
EPIDEMIOLOGICAL FEATURES OF COVID-19 FAMILY OUTBREAKS IN CHILDREN
}

Ludmila BIRCA 2,1, Diana SPATARU1,2, Stela CORNILOVA ${ }^{2,1}$, Viorica HEMEI², Olesea AIOANI2

${ }^{1}$ Nicolae Testemitanu State University of Medicine and Pharmacy, Republic of Moldova

2PMSI Municipal Clinical Hospital of Contagious Diseases in Children, Chisinau, Republic of Moldova

Corresponding author: Diana Spătaru, e-mail: diana.spataru@usmf.md

DOI: $10.38045 /$ ohrm.2021.4.09

CZU: 616.98:578.834.1-036.22-053.2

Keywords: COVID19 infection, children, family outbreaks, sources of infection.
Cuvinte cheie: infecția COVID-19, copii, focare familiale, surse de infecție.
Introduction. The population of all ages is susceptible to SARS-CoV-2 virus. It is important to determine the role of the child in COVID-19 cases maintenance and spreading. Some research showed that most COVID-19 cases in children were associated with their families.

Material and methods. The descriptive study is carried out on the basis of family outbreaks epidemiological peculiarities evaluation, concerning the age of the children, the onset of the disease, communities living environment. The research group included 160 family outbreaks, which required hospitalization at MCHCDC PMSI, between January and February 2021.

Results. The number of family outbreaks increased ( $n=88$ versus $n=72$ ) in February versus January 2021. The rate of outbreaks in schoolchildren increased from $37.5 \%$ in January to $53.4 \%$ in February. The onset of the disease in the outbreaks varies depending on the age category of the involved children: in 0-6 years - the parents become initially ill (40.7\%) or the disease begins simultaneously (32.55\%). In school-age children outbreaks in about half of the cases (51.35\%) the children manifest the disease the first. There is a tendency of outbreaks percentage increase in the cases where the children, the organized ones as well (from $43 \%$ to $62.5 \%$ ) constitute the primary source of infection.

Conclusions. SARS-CoV-2 viral infection epidemiological particularities evaluation in family outbreaks is one of the most important conditions in developing action and response strategies to COVID-19 infection in the community.

\section{PARTICULARITĂTI EPIDEMIOLOGICE ALE FOCARELOR FAMILIALE COVID-19 CU IMPLICAREA COPIILOR}

Introducere. Populația de toate vârstele este susceptibilă la SARS-CoV-2. Este important însă să se determine rolul copilului în menținerea și răspândirea cazurilor de COVID-19. Unele cercetări au arătat că majoritatea cazurilor de COVID-19 la copii au fost asociate familiei.

Material și metode. Determinarea particularităților epidemiologice ale focarelor familiale, în funcție de vârsta copiilor, debutul bolii, mediul de trai, apartenența la colectivități a fost realizată în baza unui studiu descriptiv. Lotul de cercetare a inclus 160 de focare familiale, care au necesitat spitalizare în IMSP SCMBCC, în perioada ianuarie-februarie 2021.

Rezultate. In luna februarie vs luna ianuarie 2021 a crescut numărul de focare familiale ( $n=88$ vs $n=72$ ). Rata focarelor cu implicarea elevilor s-a majorat de la 37,5\% în ianuarie până la 53,4\% în luna februarie. Debutul bolii în focarele familiale variază în funcție de categoria de vârstă a copiilor implicați: vârsta 0-6 ani - inițial se îmbolnăvesc părinții $(40,7 \%)$ sau se înregistrează un debut concomitent al bolii (32,55\%); vârstă școlară - în circa o jumătate dintre cazuri (51,35\%) copilul primul manifestă boala. Se atestă o tendință de creștere a ponderii focarelor în care copii reprezintă surse primare de infecție, precum și a focarelor cu implicarea copiilor organizați (de la 43\% la 62,5\%).

Concluzii. Determinarea particularităților epidemiologice ale infecției cu virusul SARS$\mathrm{CoV}$-2 în cadrul focarelor familiale reprezintă una dintre condițiile importante în elaborarea strategiilor de acțiune și de răspuns la infecția COVID-19 în comunitate. 


\section{INTRODUCTION}

COVID-19 infection has caused huge medical, social and economic impact, rapidly becoming a major public health problem worldwide (1). In 2020, COVID-19 infection control measures largely depended on non-specific prophylactic measures such as: physical distance, hand hygiene, protective masks wear, isolation and quarantine, thus outbreaks investigation became a very important aspect in transmission prevention (2).

The schools were closed in more than 190 countries around the world, affecting 1.57 billion children, and about $90 \%$ of the world's student population in the first months of COVID-19 pandemic (3).

The family environment involves close contact and thus a high probability rate of transmission no matter what age or society position (4). The spread of COVID-19 within families is an accelerator of the epidemic. Non-specific prophylactic measures are considered to be effective, but there is little opportunity to support community members reducing the risk of COVID-19 in families (5).

Home isolation measures - implemented as a means in pandemic control have reduced human mobility (6). Thus, the time spent at home increased and SARS-CoV-2 virus transmission in households intensified. Some countries, such as Iceland, have reported a shift in exposure from international travel and social exposure to domestic exposure. In China, the most cases locally generated were detected in households (7).

The studies done to determine the spread of Covid-19 infection in familial outbreaks are useful to obtain clear data on SARS-CoV-2 transmission dynamics and to gain insight into the main determinants (8). Some researches elucidate the role of households/families as one of the most important SARS-CoV-2 infections spread in the population $(4,8,9,10)$. Households will continue to be a significant place for SARS-CoV-2 transmission, as patients with suspected or confirmed SARS-CoV-2 infection are asked to self-isolate at home (10).

A study conducted in China determined that family contacts present the highest risk of transmission, being followed by social and community contacts. Health care contacts constitute the lowest risk, indicating adequate protection measurees for patients and medical staff from Hunan (6). In addition, susceptibility to infection (de- fined as the risk of primary case infection) varies with age: children aged $0-12$ are significantly less sensitive than people aged 26-64, but the patients over 65 are much more sensitive (6).

Despite its worldwide spread, COVID-19 epidemiological and clinical patterns remain largely unclear, especially among children (11). Published data on the transmission of SARS-CoV-2 among children in healthcare workers (HCW) families are few (12). A study realized in Spain during the first pandemic wave revealed a high level of SARS-CoV-2 detection in healthcare workers' children, especially when both parents were symptomatic, emphasizing the great impact of family groups in SARS-CoV-2 transmission (12).

Data on contacts epidemiological surveillance in Shenzhen, China, confirmed the role of children in transmitting the infection, with similar data being reported both in children, adults from individual households (13).

Other studies (Netherlands) suggest that SARSCoV-2 infection is more commonly spread among adults or from adult family members to children (13), especially during the period when schools were closed (13). Family transmission can be conditioned by socio-cultural factors and living conditions; therefore, the results cannot be extrapolated to other populations. Nowadays data on familial transmission of SARS-CoV-2 infection in Western Europe and the role of children in this process are limited (8).

Multiple studies revealed that children of all ages were susceptible to SARS-CoV-2 infection (11). Emerging evidence suggests that young children are at higher risk of COVID-19 than it was initially foreseen (14). Continuous surveillance is needed to understand better the epidemiology, clinical model and transmission of COVID-19 in order to develop effective preventive strategies against COVID-19 in the paediatric population (14).

Several examples of SARS-CoV-2 clusters were linked to a wide range of settings, especially the indoor ones. Few reports came from schools, more from households, and an increasingly high number was reported in hospitals and nursing homes across Europe (10).

Some experts say that the opening of schools, despite the safety measures for symptoms monitoring, personal hygiene, masks wear and distancing among students - did not cause 
significant outbreaks concerning school (3). However, accumulating the data, it was found that a significant proportion of children and adolescents are asymptomatic or less symptomatic. Summing up can be said that children and adolescents with COVID-19 appear to have higher SARS-CoV-2 viral loads in nasopharyngeal lavage than adults.

Thus, the impact of school opening in diverse epidemiological situations from different communities must be carefully examined (3). Coplex epidemiological studies are needed to determine the role of children in the spread of SARS-CoV-2 infection, returning to organized preschool activities and education at all levels (15).

Study hypothesis: the role of children in SARSCoV-2 infection transmission was initially underestimated the analysis of the epidemiological features of family outbreaks may highlight the impact of the children in infection spread in these outbreaks.

\section{MATERIAL AND METHODS}

The aim of the study was to determine some epidemiological features of COVID-19family outbreaks, emphasizing the impact of the child in the epidemic chain maintenance.

A cross-sectional descriptive observational epidemiological study of 160 family outbreaks sample was performed for this purpose. The primary material used for this research was collected from the clinical observation sheets of the patients diagnosed with COVID-19, who were hospitalized in SCMBCC IMSP, during JanuaryFebruary, 2021. The study involved Covid-19 infection family outbreaks epidemiological features determination. The information was grouped and analysed according to the age of the children, the onset of the disease, the primary sources of the outbreak, the living environment, the children's belonging to communities. The statistical processing of the collected data was performed with the help of Microsoft Excel 2019 program. Statistic assessment was carried out by comparative checking of the studied indices, establishing the statistical threshold of $\mathrm{p}<0,05$.

\section{RESULTS}

To assess the role of the child in the transmission of SARS-CoV-2 infection, we analysed the epidemiological features of COVID-19 in people with family outbreaks. It should be noted that at the stage of this research, in accordance with the provisions of PCN New Corona viral Infection (COVID-19), edition IV, hospitalization was mandatory for all the children with COVID-19, excepting those with asymptomatic forms. The motivation for conducting the study was Covid19 morbidity decrease in the Republic of Moldova in January (16) and the increase in the number of cases in February (17), during the reopening of educational institutions in JanuaryFebruary 2021.

Out of the total outbreaks analysed for January, it was found that the outbreaks which predominate involved preschool children - 45 (62.5\%) versus those of school-age children 27 outbreaks $(37.5 \%)$, there is no statistical difference $t=2,09$, $\mathrm{p}>0,05$.

In the group of outbreaks with preschool children - 25 (34.72\%) were the outbreaks involving children up to 1 year old. Family outbreaks concerning the children up to 1 year came from urban areas in $72 \%$ cases (tab. 1 ).

Table 1. Age structure, living environment in COVID-19 family outbreaks, January, 2021.

\begin{tabular}{|c|c|c|c|c|c|c|c|c|}
\hline \multirow{2}{*}{$\begin{array}{l}\text { Age of children in } \\
\text { family outbreaks }\end{array}$} & \multicolumn{2}{|c|}{ Nr. outbreaks } & \multicolumn{2}{|c|}{ urban } & \multicolumn{2}{|c|}{ rural } & \multicolumn{2}{|c|}{ organised* } \\
\hline & $\mathrm{n}$ & $\%$ & $\mathrm{n}$ & $\%$ & $\mathrm{n}$ & $\%$ & $\mathrm{n}$ & $\%$ \\
\hline 0-12 months & 25 & 34.72 & 18 & 72.0 & 7 & 28.0 & 0 & 0.0 \\
\hline 1-3 years & 13 & 18.06 & 11 & 84.62 & 2 & 15.38 & 2 & 15.40 \\
\hline 4-6 years & 7 & 9.72 & 7 & 100.0 & 0 & 0.0 & 5 & 71.42 \\
\hline Total preschoolers & 45 & 62.5 & 36 & 80.0 & 9 & 20.0 & 7 & 15.55 \\
\hline 7-10 years & 4 & 5.56 & 4 & 100.0 & 0 & 0.0 & 4 & 100.0 \\
\hline$\geq 11$ years & 19 & 26.39 & 16 & 84.21 & 3 & 15.79 & 16 & 84.21 \\
\hline Different ages & 4 & 5.56 & 3 & 75.0 & 1 & 25.0 & 4 & 100.0 \\
\hline Total pupils & 27 & 37.5 & 23 & 85.18 & 4 & 14.82 & 24 & 88.88 \\
\hline Total, outbreaks & 72 & 100.0 & 59 & 81.9 & 13 & 18.1 & 31 & 43.05 \\
\hline
\end{tabular}

Note: * belong to a social group or communities (nursery, kindergarten, school) 
An important element of our analysis was to determine the primary sources of infection in the family outbreak. Thus, it was established that in infants outbreaks (0-12 months) the first to show signs of disease in about half $(52.0 \%)$ of cases were parents, in $24.0 \%$ of cases the onset of the disease occurred simultaneously in children and parents, which denotes a possible common exposure to the infectious agent, but in other $24.0 \%$ of outbreaks - the child was the first to manifest the disease (tab. 2).

In the case of the family outbreaks involving the children aged 1-3 years, analysed for January most came from urban areas, pre-school children accounted $84.61 \%$ (tab. 1). Parents' infection was registered in $46.15 \%$, concomitantly in children and parents $-46.15 \%$, and the onset of the disease in children $-7.70 \%$ of outbreaks (tab. 2).

Table 2. Primary sources of COVID-19 infection in family outbreaks, January, 2021.

\begin{tabular}{lccccccc}
\hline \multirow{2}{*}{$\begin{array}{c}\text { Age of children in } \\
\text { family outbreaks }\end{array}$} & \multicolumn{6}{c}{ The onset of the disease in the family outbreak } \\
\cline { 2 - 9 } & \multicolumn{2}{c}{ concomitant } & \multicolumn{2}{c}{ child } & \multicolumn{2}{c}{ parents } & \multicolumn{1}{c}{ total } \\
\cline { 2 - 9 } & $\mathrm{n}$ & $\%$ & $\mathrm{n}$ & $\%$ & $\mathrm{n}$ & $\%$ & $\mathrm{n}$ \\
\hline $\mathbf{0 - 1 2}$ months & 6 & 24.00 & 6 & 24.00 & 13 & 52.00 & 25 \\
\hline 1-3 years & 6 & 46.15 & 1 & 7.70 & 6 & 46.15 & 13 \\
\hline 4-6 years & 1 & 14.29 & 2 & 28.57 & 4 & 57.14 & 7 \\
\hline Total preschoolers & 13 & 28.89 & 9 & 20.00 & 23 & 51.11 & 45 \\
\hline 7-10 years & 1 & 25.0 & 2 & 50.00 & 1 & 25.0 & 4 \\
\hline $\mathbf{2 1 1}$ years & 0 & 0.00 & 9 & 47.37 & 10 & 52.63 & 19 \\
\hline Different ages & 1 & 25.00 & 2 & 50.00 & 1 & 25.00 & 4 \\
\hline Total pupils & 2 & 7.41 & 13 & 48.15 & 12 & 44.44 & 27 \\
\hline Total & 15 & 20.83 & 22 & 30.56 & 35 & 48.61 & 72 \\
\hline
\end{tabular}

In the case of family outbreaks in children aged 4-6 years - the majority (71.42\%) of children were organised (tab. 1). The disease started primarily in adults - 57.14\%, simultaneously in adults and children $-14.29 \%$ of cases, and in $28.57 \%$ the child became ill first (tab. 2).

Generally, in the focus group involving preschool children, hospitalized in January (tab. 2), the first to show signs of COVID-19 were the adults (parents or caregivers) $-51.11 \%$, concomitant onset of the disease $-28.89 \%$ and in only $20.0 \%$ of outbreaks the child was the primary infected family member.

Among the outbreaks in school-age children, the highest percentage $(70.37 \%)$ was in children aged 11 and more. The majority (84.21\%) of chil-dren were organized, from urban areas (tab. 1 ). The first in the family to get infected were the adults about $1 / 2$ (52.63\%) of cases; in $47.36 \%$ the children were the first to show clinical signs (tab. 2).

An interesting element is the fact that in schoolage children outbreaks, the children hospitalized in January, were the first to manifest the disease being the primary sources of infection in families - 13 outbreaks (48.15\%), in other 12 outbreaks (44.44\%) - the parents were initially affected, and in only 2 outbreaks (7.40\%) the onset of the disease was concomitant both in children and adults (tab. 2).

Analysing the data for January it was determined that $81.9 \%$ of the total outbreaks were from urban areas in $43.05 \%$ of outbreaks (tab. 1). The adults were predominantly registered as primary sources of infection in the family $(48,61 \%)$ or concomitant illness was observed $20.83 \%$ of outbreaks), which does not exclude common exposure to the source of infection. Only in $30.56 \%$ outbreaks the onset of the disease was primarily reported to affect children (tab. 2).

In February, it was observed the following rate preschool children - 41 (46.59\%), school-age children 47 (53.41\%), organized children increased to $62.50 \%(\mathrm{t}=1.76$, $\mathrm{p}>0.05$ ) (tab. 3 ).

Analysing the data for February family outbreaks, the following particularities were established: infants (0-12 months) in 16 outbreaks, of which $37.50 \%$ of cases in caregivers, or children - the first showing clinical symptoms. In the rest of the cases $(25.0 \%)$ the clinical signs started at the same time (tab. 4).

In February, young children (1-3 years) in 13 outbreaks, $84,62 \%$ from urban areas (tab. 3) 
Table 3. Structure of epidemiological features in COVID-19 family outbreaks, February, 2021.

\begin{tabular}{lcccccccc}
\hline \multirow{2}{*}{$\begin{array}{c}\text { Age of children in family } \\
\text { outbreaks }\end{array}$} & \multicolumn{2}{c}{ Nr. outbreaks } & \multicolumn{2}{c}{ urban } & \multicolumn{2}{c}{ rural } & \multicolumn{2}{c}{ organised* $^{*}$} \\
\cline { 2 - 11 } & $\mathrm{n}$ & $\%$ & $\mathrm{n}$ & $\%$ & $\mathrm{n}$ & $\%$ & $\mathrm{n}$ & $\%$ \\
\hline $\mathbf{0 - 1 2}$ months & 16 & 18.18 & 12 & 75.00 & 4 & 25.0 & 0 & 0.00 \\
\hline $\mathbf{1 - 3}$ years & 13 & 14.77 & 11 & 84.62 & 2 & 15.38 & 6 & 46.15 \\
\hline 4-6 years & 12 & 13.64 & 11 & 91.67 & 1 & 8.33 & 8 & 66.67 \\
\hline Total pre-schoolers & 41 & 46.59 & 34 & 82.93 & 7 & 17.07 & 14 & 34.14 \\
\hline 7-10 years & 10 & 11.36 & 6 & 60.00 & 4 & 40.0 & 9 & 90.00 \\
\hline >11 years & 26 & 29.55 & 20 & 76.92 & 6 & 23.08 & 25 & 96.15 \\
\hline Different ages & 11 & 12.50 & 8 & 72.73 & 3 & 27.27 & 7 & 63.63 \\
\hline Total pupils & 47 & 53.41 & 34 & 72.34 & 13 & 27.66 & 41 & 87.23 \\
\hline Total, outbreaks & 88 & 100.0 & 68 & 77.27 & 20 & 22.73 & 55 & 62.50 \\
\hline
\end{tabular}

Note: ${ }^{*}$ belong to a social group or communities (nursery, kindergarten, school)

were the first to get ill in $53.84 \%$ of outbreaks, in $23.08 \%$ of outbreaks the adults were the first to get infected - or concomitant infection occurred (tab. 4).

In February, pre-schoolers (4-6 years old), 91.67\% from urban areas were identified -12 outbreaks. The disease manifested more fre- quently in adults - 5 outbreaks (41.67\%), in children $-33.33 \%$, simultaneous - $25.0 \%$ (tab.4).

In school-age children outbreaks - 53.19\% of cases the child was the first to manifest the disease, $40.42 \%$ - the first to become infected were the parents, but in $6.38 \%$ outbreaks - the disease was concomitant (tab. 4).

Table 4. Primary sources of COVID-19 infection in family outbreaks, February, 2021.

\begin{tabular}{|c|c|c|c|c|c|c|c|}
\hline \multirow{3}{*}{$\begin{array}{c}\text { Age of children in family } \\
\text { outbreaks }\end{array}$} & \multicolumn{7}{|c|}{ The onset of the disease in the family outbreak } \\
\hline & \multicolumn{2}{|c|}{ concomitant } & \multicolumn{2}{|c|}{ child } & \multicolumn{2}{|c|}{ parents } & \multirow{2}{*}{$\frac{\text { total }}{\mathrm{n}}$} \\
\hline & $\mathrm{n}$ & $\%$ & $\mathrm{n}$ & $\%$ & $\mathrm{n}$ & $\%$ & \\
\hline 0-12 months & 4 & 25,0 & 6 & 37.50 & 6 & 37.50 & 16 \\
\hline 1-3 years & 3 & 23.08 & 7 & 53.84 & 3 & 23.08 & 13 \\
\hline 4-6 years & 3 & 25.00 & 4 & 33.33 & 5 & 41.67 & 12 \\
\hline Total pre-schoolers & 10 & 24.39 & 19 & 46.34 & 12 & 29.27 & 41 \\
\hline 7-10 years & 0 & 0,0 & 7 & 70.00 & 3 & 30.00 & 10 \\
\hline$\geq 11$ years & 4 & 15.39 & 12 & 46.15 & 10 & 38.46 & 26 \\
\hline Different ages & 4 & 36.36 & 4 & 36.36 & 3 & 27.28 & 11 \\
\hline Total pupils & 3 & 6.38 & 25 & 53.19 & 19 & 40.43 & 47 \\
\hline Total & 13 & 14.77 & 44 & 50.00 & 31 & 35.23 & 88 \\
\hline
\end{tabular}

Overview, some epidemiological features of COVID-19 were found in February - a higher percentage (53.41\% in February versus $37.5 \%$ in January, $\mathrm{t}=1.33, \mathrm{p}>0.05$ ) of outbreaks involving school-age children; the predominance of the onset of the disease in children and an increase in the percentage of organized children (from $43 \%$ in January to $62.5 \%$ in February, $t=1.76$, $\mathrm{p}>0.05)$. In February, there was a higher percentage $(50.0 \%$ versus $30.56 \%, t=1.54, p>0.05)$ of outbreaks in which children were the first to get sick.

\section{DISCUSSIONS}

This study describes the impact of the child in COVID-19 infection transmission, even though it was thought to be insignificant. The opening of schools in Chisinau can be considered a catalyst in COVID-19 transmission among paediatric population. We can emphasize that the selection of measures to control COVID-19 infection in the community must also estimate these particularities of infection transmission among children, in the family, or at school. The opening of schools is accepted with good safety measures, symptoms monitoring, personal hygiene, masks wear and social distance.

Data accumulation and analysis proved that a percentage of asymptomatic or symptomatic children can be significant (18). Moreover, children and adolescents with COVID-19 have higher viral loads than adults do in the early stages of 
the disease $(19,20,21)$.

Schools and kindergartens closure and reopening is a major issue of education, politics and public health worldwide. There are concerns about the transmission of SARS-CoV-2 virus among children and teachers in the school environment (3).

At the same time, there are limited data on transmission among children that could lead to major outbreaks, especially in school. A systematic review suggested that children are unlikely to be the most important factors in COVID-19 pandemic (22). It is unclear whether the dynamics of the virus transmission in the paediatric population differs from that of adults, or this may be because most schools remain closed for extended periods there may be other factors that need exploration.

However, the most common sources of infection for paediatric cases of COVID-19 appear to be members of their adult family according to some studies children are not the primary source of infection and have not caused major outbreaks in communities (23). Referring to our results, where children were the source of infection in their families there is a significant number of outbreaks, thus we can conclude that they are involved in catalysing the epidemic process in SARS-CoV-2 virus infection.

Our study suggests the need to apply antiepidemic measures to the child population. Proper masks wear is a way to reduce the spread of the virus in the community by stopping its spread through respiratory secretions from sources of infection, including children. Wearing protective masks in public, children can help stop the spread of COVID-19 - and to protect their families, communities and themselves.

The teachers in institutions can be exposed to a much higher risk of infection with SARS-CoV-2 virus, interacting with children who are an important source of infection. Teachers' protection and prevention from SARS-CoV-2 viral infection is vaccination.

This entails close epidemiological surveillance of children, especially adolescents, taking into account their increased potential for infection outside family outbreaks. In this context, the results of our study are consistent with previously published studies (24).

\section{CONCLUSIONS}

1. The number of outbreaks requiring hospitalization at Municipal Clinical Hospital of Contagious Diseases in Children increased in February compared to January.

2. It was determined in January that in family outbreaks the hospitalized adults as primary sources of infection were predominantly registered or due to a concomitant illness which was determined, without excluding the common exposure to the source of infection.

3. A higher percentage of outbreaks involving school-age children made in February; an increase in the percentage of organized children and a higher percentage of outbreaks in which children became ill the first.

4. The epidemiological aspects of SARS-CoV-2 virus transmission in family outbreaks are necessary in the development of action and response strategies in COVID-19 infection.

\section{CONFLICT OF INTERESTS}

Nothing to declare.

\section{REFERENCES}

1. Paraschiv A, Guţu L, Spătaru D, Berdeu I, Sofronie $\mathrm{V}$, Nastas A. Aspecte epidemiologice în infecţia COVID-19 bazate pe evidenţe curente: articol de sinteză narativă. MJHS. 2020; 23.

2. Lash RR, Moonan PK, Byers BL, Bonacci RA, Bonner KE, Donahue $\mathrm{M}$, et al. COVID-19 Case Investigation and Contact Tracing in the US, 2020. JAMA Netw open. 2021;4(6):e2115850. Available from: http://www.ncbi.nlm.nih.gov/pubmed/3408113
5 [Accessed 2021 Jun 6].

3. Yoon Y, Kim KR, Park H, Kim S, Kim YJ. Stepwise School Opening and an Impact on the Epidemiology of COVID-19 in the Children.J Korean Med Sci. 2020;35(46). Available from:/pmc/articles/ PMC7707922/ [Accessed 2021 Jun 9].

4. Reukers DFM, Van Boven M, Meijer A, Rots N, Reusken C, Roof I, et al. High infection attack rates of SARS-CoV-2 in Dutch households revealed by 
dense sampling. medRxiv. 2021;2021.01.26. 21250512. doi:10.1101/2021.01.26.21250512

5. Wang Y, Tian H, Zhang L, Zhang M, Guo D, Wu W, et al. Reduction of secondary transmission of SARS-CoV-2 in households by face mask use, disinfection and social distancing: a cohort study in Beijing, China. BMJ Glob Heal. 2020;5(5):2794. Available from: http://gh.bmj.com/ [Accessed 2021 Jun 8].

6. Sun K, Wang W, Gao L, et al. Transmission heterogeneities, kinet-ics, and controllability of SARSCoV-2. Science. Published online November 24, 2020. doi:10.1126/science.abe2424.

7. Madewell ZJ, Yang Y, Longini IM, Halloran ME, Dean NE. Household transmission of SARS-CoV-2: a systematic review and meta-analysis of secondary attack rate. Prepr Serv Heal Sci. 2020. Available from: http://www.ncbi.nlm.nih. gov/pubmed/32766596 [Accessed 2021 Jun 6].

8. Hoog MM de, Verberk J, Westerhof I, Goethem S van, Lammens C, Ieven GM, et al. Transmission of SARS-CoV-2 within households: a prospective cohort study in the Netherlands and Belgium - Interim results. medRxiv 2021.04.23.21255846; doi: https://doi.org/10.1101/2021.04.23. 212558469.

9. Tabatabaeizadeh SA. Airborne transmission of COVID-19 and the role of face mask to prevent it: a systematic review and meta-analysis. European Journal of Medical Research. 2021;26. Available from: https://pubmed.ncbi.nlm.nih.gov/ 33388089/ [Accessed 2021 Jun 6].

10. Leclerc QJ, Fuller NM, Knight LE, Funk S, Knight GM. What settings have been linked to SARS-CoV2 transmission clusters? Wellcome Open Res. 2020;5. Available from: /pmc/articles/ PMC7327724/ [Accessed 2021 Jun 6].

11. Dong Y, Dong Y, Mo X, Hu Y, Qi X, Jiang F, et al. Epidemiology of COVID-19 among children in China. Pediatrics. American Academy of Pediatrics; 2020;145. doi:10.1542/peds.2020-0702

12. Méndez-Echevarría A, Sainz T, de Felipe B, Alcolea S, Olbrich P, Goycochea-Valdivia WA, et al. High Rates of SARS-CoV-2 Family Transmission in Children of Healthcare Workers During the First Pandemic Wave in Madrid, Spain. Pediatr Infect Dis J. 2021;40(5):e185-8. Available from: https://journals.lww.com/10.1097/INF.0000000 000003088 [Accessed 2021 Apr 18].

13. Munro APS, Faust SN. Children are not COVID-19 super spreaders: Time to go back to school. Vol. 105, Archives of Disease in Childhood. 2020;105: 618-9. doi:10.1136/archdischild-2020-319474

14. Bhuiyan MU, Stiboy E, Hassan MZ, Chan M, Islam MS, Haider N, et al. Epidemiology of COVID-19 infection in young children under five years: A systematic review and meta-analysis. Vol. 39, Vaccine. 2021;39:667-77. Available from: https://pubmed.ncbi.nlm.nih.gov/33342635/ [Accessed 2021 Apr 18].
15. Plăcintă G, Ştirbu T, Croitoru D. Infecţia SARSCoV-2 la copii: studiu bibliografic Infection with SARS-CoV-2 in children: bibliographic study. $R e$ vista de Ştiinţe ale Sănătăţii din Moldova, 2020, 24.2: 84-98.

16. Raport săptămânal COVID-19, 10.01.2021. Available from: https://msmps.gov.md/wpcontent/uploads/2021/01/10.01.2020_COVID19.pdf [Accessed 2021 Jun 10].

17. Comisia Naţională Extraordinară de Sănătate Publică nr. 47 din 26 februarie 2021. Available from: https://gov.md/sites/default/files/ hotarirea_cnesp_nr.47_26.02.2021.pdf [Accessed 2021 Jun 10].

18. Wu Z, McGoogan JM. Characteristics of and Important Lessons from the Coronavirus Disease 2019 (COVID-19) Outbreak in China: Summary of a Report of 72314 Cases from the Chinese Center for Disease Control and Prevention. JAMA - Journal of the American Medical Association. 2020;323: 1239-42. Available from: https://pubmed. ncbi. nlm.nih.gov/32091533/ [Accessed 2021 Jun 10].

19. Jones RM, Brosseau LM. Aerosol transmission of infectious disease. J Occup Environ Med. 2015; 57: 501- 508. https://doi.org/10.1097/JOM. 0000000000000448

20. Wölfel R, Corman VM, Guggemos W, Seilmaier M, Zange S, Müller MA, et al. Virological assessment of hospitalized patients with COVID-2019. Nature. 2020;581(7809):465-9. Available from: https://pubmed.ncbi.nlm.nih.gov/32235945/ [Accessed 2021 Jun 10].

21. Han MS, Seong MW, Kim N, Shin S, Cho SI, Park H, et al. Viral RNA load in mildly symptomatic and asymptomatic children with COVID-19, Seoul, South Korea. Emerg Infect Dis. 2020;26(10):24979. Available from: https://pubmed.ncbi.nlm. nih.gov/32497001/ [Accessed 2021 Jun 10].

22. Ludvigsson JF. Children are unlikely to be the main drivers of the COVID-19 pandemic - A systematic review. Acta Paediatrica. 2020;109:152530. Available from: https://pubmed.ncbi.nlm.nih. gov/32430964/ [Accessed 2021 Jun 10].

23. Lee $B$, Raszka W V. COVID-19 transmission and children: The child is not to blame [Internet]. Pediatrics. 2020;146. Available from: https://pubmed.ncbi.nlm.nih.gov/32457212/ [Accessed 2021 Jun 10].

24. Chu DK, Akl EA, Duda S, Solo K, Yaacoub S, Schünemann HJ, et al. Physical distancing, face masks, and eye protection to prevent person-to- person transmission of SARS-CoV-2 and COVID-19: a systematic review and meta-analysis. 2020;395 (10242): 1973-87. Available from: https://pubmed.ncbi. nlm.nih.gov/32497510/ [Accessed 2021 Jun 10]. 
Date of receipt of the manuscript: 07/07/2021 Date of acceptance for publication: 22/09/2021

Ludmila BIRCA, ORCID ID: 0000-0003-4399-7528

Diana SPATARU, ORCID ID: 0000-0002-9938-3173

Stela CORNILOVA, ORCID ID: 0000-0002-5667-3955

Viorica HEMEI, ORCID ID: 0000-0002-7035-4459

Olesea AIOANI, ORCID ID: 0000-0002-2040-8789 